\title{
An alternative feeding system for dairy goats: Effects of free-choice feeding on milk yield and milk composition of lactating suckling Damascus goats
}

\author{
M. Görgülü, O. Güney, O. Torun, O. Özuyanık and H.R. Kutlu
}

\author{
Çukurova University Agricultural Faculty, \\ Department of Animal Science \\ 01330 Adana, Turkey
}

(Received 5 August 2002; accepted 20 December 2002)

\begin{abstract}
The present study was carried out to compare feeding methods in respect to milk yield and milk composition and to assess dietary preferences of lactating suckling Damascus goats receiving feed ingredients as multiple choices under confinement conditions in Northern Cyprus. A total of 36 Damascus goats was allocated to 4 experimental groups with three replicates comprising three goats each for a total period of 7 weeks. The treatment groups were $1.0 .5 \mathrm{~kg}$ concentrate and ad libitum lucerne hay, 2. $1.0 \mathrm{~kg}$ concentrate and ad libitum lucerne hay, 3. ad libitum total mixed ration (TMR) containing $40 \%$ lucerne hay and $60 \%$ concentrate, 4 . free choice feeding among the main feed ingredients of the concentrate (barley, soyabean meal, wheat bran) and lucerne hay. The results showed that milk yield, concentrate intake, hay intake, total feed intake, crude protein $(\mathrm{CP})$ and metabolizable energy $(\mathrm{ME})$ intakes and liveweight change were affected $(\mathrm{P}<0.05)$ by feeding methods. Choice-feeding increased dry matter, energy and protein intake and milk yield but decreased liveweight loss. Feeding methods had no significant $(\mathrm{P}>0.05)$ effects on fat, protein or dry matter contents of milk. However, lactose and non-fat-solids content were affected significantly $(\mathrm{P}<0.05)$ by feeding methods, as lactose and non-fat-solids content of the groups increased according to their concentrate intakes.

It can be concluded that TMR has satisfactory results in respect to lactational performance of suckling goats and that goats can select a diet corresponding to their nutrient requirements when they are given a choice among different feed ingredients. It is also concluded that free-choice feeding may have the potential to improve production performance of Damascus goats in early lactation.
\end{abstract}

KEY WORDS: feeding methods, choice-feeding, goat, milk yield, milk composition 


\section{INTRODUCTION}

The lactation cycle of the goat is very similar to that of cows; milk yield reaches a maximum 1-2 months after parturition and liveweight decline proceeds rapidly to a minimum about 6 weeks after parturition. Feed intake increase more slowly than milk production, and it can reach a maximum about 8 weeks after parturition (Sutton and Alderman, 2000). Therefore, feed intake does not meet nutrient requirements in early lactation and goats lose body weight in this period (AFRC, 1988).

In practice, the body condition and milk yield of lactating goats depend strictly on feeding systems. Increasing concentrate in the diet improves the nutritional status of the goat by increasing energy, protein, mineral and vitamin intake and optimises the efficiency of feed utilization for growth, gestation or milk production (Cerillo et al., 1999). However, concentrate supplementation may reduce the digestibility of dietary fibre (Archimede et al., 1995). It is possible to overcome the difficulties in concentrate use for dairy animals by assigning a proper feeding system such as total mixed ration (TMR) and free-choice feeding with feed ingredients (Görgülü et al., 1996; Fedele et al., 2002).

TMR is a good tool for solving the problem of low ruminal $\mathrm{pH}$ having a negative effect on microbial growth and milk fat content (Fox et al., 1990; Linn et al., 1994). Similarly, free- choice feeding offers a chance for the animals to select their diet (Görgülü et al., 1996; Fedele et al., 2002) and balance rumen conditions (Fedele et al., 2002), and thus may have a potential advantage in goat feeding. On pasture, goats utilize a much wider species of plants (Van Soest, 1982) compared with cattle and sheep, and select a diet that covers their nutrient requirements (Fedele et al., 2002). They prefer leaves over stems and thin leaves rather than thick ones (Odo et al., 2001). On pasture, preferences for different species depend on their availability. There are, however, two hypotheses for the dietary preferences of animals. The first is based on the fact that animals need to learn the properties of feed before they select an appropriate diet (Kyriazakis and Oldham, 1993; Görgülü et al., 1996; Fedele et al., 2002). The second is based on some "unlearned appetites" for specific nutrients (Kutlu and Forbes, 1993; Kyriazakis and Oldham, 1993).

The aims of the present study are: 1. to compare feeding methods in respect to milk yield and milk composition and 2. to assess the diet preferences of the Damascus goat in the pre-weaning period when feed ingredients are offered as multiple choices under confinement conditions in Northern Cyprus.

\section{MATERIAL AND METHODS}

The study was carried out on the Ercan State Farm in Northern Cyprus, which lies on longitude $33^{\circ} 30^{\prime} \mathrm{E}$ and latitude $35^{\circ} 75^{\prime} \mathrm{N}$. Mean temperature 
and rainfall for the experimental period were $20.9^{\circ} \mathrm{C}$ and $39.5 \mathrm{~mm}$ per month, respectively.

The study was conducted with a total of 36 Damascus goats in the second lactation and having twin kids. The goats, $12 \pm 0.7$ days postpartum, were allocated to 4 experimental groups with tree replicates comprising three goats each in a 6 $\mathrm{m}^{2}(2 \times 3 \mathrm{~m})$ pen. Each pen had one $0.4 \mathrm{~m} \times 2 \times 0.3 \mathrm{~m}$ trough and a 15 -L bucket for fresh water. The feed trough of the choice-fed group was divided into four equal parts to present feed ingredients separately, but ad libitum. The goats were assigned to treatments according to the liveweight and milk yield at the beginning of the experiment. The experiment, including a two-week preliminary period, lasted for a total of 9 weeks. During the second week of the preliminary period, the goats of the choice-feeding group were given the opportunity to experience the ingredients that were subsequently given as choices. During this training period lucerne straw was all times available and the other ingredients (barley, soyabean meal and wheat bran) were offered alternately every three days for a period of 6 days as adapted from Görgülü et al. (1996). Liveweight changes were recorded from the beginning of the preliminary period, milk yield and feed intake were determined after the preliminary period.

Compound feed as a concentrate and lucerne hay or lucerne straw (made from hay by chopping to a size of $1-2 \mathrm{~cm}$ ) as roughage were used in the experiment. The composition and nutrient contents of the concentrate and lucerne are presented in Table 1.

Table 1

Composition and nutrient contents of the concentrate and lucerne used in the experiment

\begin{tabular}{lrl}
\hline Ingredients & $\mathrm{g} / \mathrm{kg}$ & \\
\hline Barley & 646.9 & \\
Soyabean meal (44\%CP) & 131.0 & \\
Wheat bran & 187.6 & \\
Mineral-vitamin premix & 2.5 & \\
Ground limestone & 24.5 & \\
Common salt & 7.5 & \\
& & \\
Chemical composition (DM basis), \% & & Lucerne \\
$\quad$ dry matter & 89.0 & 1.0 \\
crude protein & 17.9 & 27.3 \\
crude fibre & 7.8 & 1.8 \\
$\quad$ ether extract & 2.4 & 7.7 \\
crude ash & 3.9 & 1.2 \\
Ca, ${ }^{1}$ & 1.1 & 0.2 \\
P, ${ }^{1}$ ME, Mcal $/ \mathrm{kg}^{1}$ & 0.6 & 1.98 \\
\hline
\end{tabular}

${ }^{1}$ calculation based on the values published by NRC (1981) 
The treatment groups were $1.0 .5 \mathrm{~kg}$ concentrate and ad libitum lucerne hay, $2.1 .0 \mathrm{~kg}$ concentrate and ad libitum lucerne hay, 3. ad libitum total mixed ration (TMR) containing $40 \%$ lucerne straw and $60 \%$ concentrate, 4 . free-choice feeding ad libitum among the main feed ingredients (barley, soyabean meal, wheat bran) of the concentrate and lucerne hay. The concentrate and lucerne were given as the feed basis. Lucerne hay was presented 3-4 times a day to the groups receiving 0.5 and $1.0 \mathrm{~kg}$ supplemental concentrate and choice-fed group to prevent excess refusal and preference of leaves to stems.

Each of the main feed ingredients, except lucerne hay, given to the choicefeeding group was mixed with mineral, vitamin and limestone at the levels used in the TMR in order to ensure micronutrient intake of the choice-fed group and also to prevent any possible effect of micronutrients on feed ingredient selection. Fresh water was given ad libitum during the entire experimental period to all animals. Kids and their dams were housed separately and the kids were allowed to suckle their dams one hour in the morning and one hour in the afternoon every day during the experiment except on weekly milk control days, when daily milk yield was determined by summing up morning $(07: 00 \mathrm{~h})$ milk and afternoon $(16: 00 \mathrm{~h})$ milk by hand milking. Representative milk samples from the morning milk were taken and the dry matter, fat, protein, and lactose contents of milk were analysed weekly by MilkoScan S 50 (Foss Electronic, Hillerod, Denmark).

Proximate analyses of feeds were performed according to AOAC (1998). Metabolizable energy, $\mathrm{Ca}$ and $\mathrm{P}$ content of the diets were calculated based on the table values published by NRC (1981).

The experiment was carried out according to a completely randomised design and data obtained in the experiment were analysed by the GLM procedure in SAS (1985). Differences of means were separated by Duncan's New Multiple Range Test. The differences between TMR and the diet chosen by goats with respect to ingredients and chemical compositions were determined by the One Sample T-Test (SAS,1985).

\section{RESULTS}

The results obtained in the study are presented in Tables 2 and 3.

The goats in the choice-fed group changed their diet preferences as the experimental period progressed; they increased their dietary energy level and decreased the dietary protein level. At the end of experiment, the diet chosen by the goats in the choice-feeding group had a lower barley content $(\mathrm{P}<0.05)$, but higher soyabean meal and wheat bran contents than TMR (Table 2). According to the ingredient preferences of goats in the choice-feeding group, their diet also had less ME and a higher protein level $(\mathrm{P}<0.05)$ than in TMR. However, the goats in 
the choice-feeding group selected a diet containing a similar crude fibre content to that of TMR.

TABLE 2

Compositions of TMR and the diets selected by choice fed goats

\begin{tabular}{lrccc}
\hline \multirow{2}{*}{ Ingredients, $\mathrm{g} / \mathrm{kg}$} & \multirow{2}{*}{ TMR } & \multicolumn{3}{c}{ Diets selected by goats } \\
\cline { 3 - 5 } & & $1-4$ week & $5-7$ week & overall \\
\hline Barley & 388.1 & $263.9^{*}$ & $350.1^{*}$ & $304.6^{*}$ \\
Soyabean meal (44\%CP) & 78.6 & $131.8^{*}$ & 113.8 & 123.3 \\
Wheat bran & 112.6 & 127.1 & $176.3^{*}$ & $150.4^{*}$ \\
Mineral-vitamin premix & 1.5 & 0.8 & 1.0 & 0.9 \\
Ground limestone & 14.7 & 7.9 & 9.6 & 8.7 \\
Salt & 4.5 & 2.4 & 3.0 & 2.7 \\
Lucerne & 400.0 & $466.1^{*}$ & $346.2^{*}$ & 409.4 \\
& & & & \\
Chemical composition (DM basis), \% & & & & \\
$\quad$ dry matter & 89.8 & 89.9 & 89.7 & 89.8 \\
$\quad$ crude protein & 17.3 & $19.7^{*}$ & $18.7^{*}$ & $19.2^{*}$ \\
$\quad$ crude fibre & 15.7 & $17.3^{*}$ & 15.0 & 16.2 \\
$\quad$ ether extract & 2.1 & 2.2 & 2.3 & 2.2 \\
$\quad$ crude ash & 7.5 & 7.2 & 6.9 & 7.1 \\
Ca & 1.2 & 1.0 & 0.9 & 1.0 \\
P & 0.4 & 0.5 & 0.5 & 0.5 \\
ME, Mcal/kg & & & & \\
\hline
\end{tabular}

the difference between TMR and the diet selected by goats in different period of the trial is significantly different* $\mathrm{P}<0.05, * * \mathrm{P}<0.07$

The results at the end of the experiment showed that milk yield, concentrate, hay and total feed intake, $\mathrm{CP}$ and ME intakes and liveweight change were affected $(\mathrm{P}<0.05)$ by feeding methods (Table 3$)$. The goats receiving $1.0 \mathrm{~kg}$ concentrate or TMR or choice feeding yielded $0.41 \mathrm{~kg} /$ day $(\mathrm{P}>0.05), 0.93 \mathrm{~kg} /$ day $(\mathrm{P}<0.05)$ and 1.74 $\mathrm{kg} /$ day $(\mathrm{P}<0.05)$ more milk than those receiving $0.5 \mathrm{~kg}$ concentrate, respectively. The goats fed on TMR and choice-feeding consumed less $(\mathrm{P}<0.05)$ hay than those fed on 0.5 and $1.0 \mathrm{~kg}$ concentrate, while the choice-fed group consumed a higher $(\mathrm{P}<0.05)$ amount of hay than those receiving TMR. With respect to concentrate intake, feeding methods had a significant effect $(\mathrm{P}<0.05)$ as the groups increased their concentrate intakes according to its availability. The highest intake was obtained in the choicefed groups, followed by the groups fed on TMR, $1 \mathrm{~kg}$ and $0.5 \mathrm{~kg}$ concentrate. The results of crude protein and metabolizable energy intakes showed a similar pattern with concentrate intake. Liveweight change was also affected $(\mathrm{P}<0.05)$ by feeding methods during the entire experimental period including the preliminary stage; all groups showed liveweight loss, which was higher for the goats on 0.5 and $1.0 \mathrm{~kg}$ concentrate than the goats receiving TMR and choice-feeding. 
TABLE 3

Dry matter intake, nutrient intakes, milk yield and composition of Damascus goat fed with different feeding systems

\begin{tabular}{|c|c|c|c|c|c|}
\hline \multirow{2}{*}{ Item } & \multicolumn{5}{|c|}{ Supplemental concentrate } \\
\hline & $0.5 \mathrm{~kg}$ & $1.0 \mathrm{~kg}$ & TMR & Choice-fed & SEM \\
\hline Body weight, kg & 76.67 & 74.11 & 73.78 & 73.44 & 0.94 \\
\hline \multicolumn{6}{|l|}{$0-4$ weeks } \\
\hline lucerne hay intake, $\mathrm{kg} /$ day & $2.68^{a}$ & $2.67^{\mathrm{a}}$ & $1.21^{\mathrm{c}}$ & $1.92^{\mathrm{b}}$ & 0.01 \\
\hline concentrate intake, $\mathrm{kg} /$ day & $0.45^{\mathrm{d}}$ & $0.89^{c}$ & $1.78^{\mathrm{b}}$ & $2.32^{\mathrm{a}}$ & 0.01 \\
\hline DMI, kg/day & $3.13^{\mathrm{c}}$ & $3.56^{\mathrm{b}}$ & $2.99^{\mathrm{d}}$ & $4.23^{\mathrm{a}}$ & 0.02 \\
\hline MEI, Mcal/day & $6.67^{\mathrm{d}}$ & $7.99^{\mathrm{b}}$ & $7.72^{\mathrm{c}}$ & $10.54^{\mathrm{a}}$ & 0.03 \\
\hline CPI, g/day & $520.17^{c}$ & $597.65^{\mathrm{b}}$ & $518.44^{c}$ & $832.27^{\mathrm{a}}$ & 2.73 \\
\hline milk yield, kg/day & $2.03^{\mathrm{c}}$ & $2.54^{\mathrm{bc}}$ & $3.06^{\mathrm{b}}$ & $4.02^{\mathrm{a}}$ & 0.15 \\
\hline lactose, $\%$ & 4.03 & 4.22 & 4.25 & 4.40 & 0.03 \\
\hline protein, $\%$ & 3.80 & 3.79 & 3.95 & 3.97 & 0.05 \\
\hline fat, $\%$ & 2.86 & 2.54 & 3.16 & 2.37 & 0.15 \\
\hline solid non fat, $\%$ & $8.82^{\mathrm{c}}$ & $8.97^{b c}$ & $9.18^{\mathrm{ab}}$ & $9.30^{\mathrm{a}}$ & 0.05 \\
\hline total solid, $\%$ & 11.68 & 11.51 & 12.34 & 11.66 & 0.16 \\
\hline \multicolumn{6}{|l|}{ 5-7 weeks } \\
\hline lucerne hay intake, $\mathrm{kg} /$ day & $2.13^{\mathrm{a}}$ & $2.09^{\mathrm{a}}$ & $1.20^{\mathrm{c}}$ & $1.37^{\mathrm{b}}$ & 0.01 \\
\hline concentrate intake, $\mathrm{kg} /$ day & $0.45^{\mathrm{d}}$ & $0.89^{c}$ & $1.76^{\mathrm{b}}$ & $2.61^{\mathrm{a}}$ & 0.01 \\
\hline DMI, kg/day & $2.58^{\mathrm{c}}$ & $2.98^{\mathrm{b}}$ & $2.96^{\mathrm{b}}$ & $3.98^{\mathrm{a}}$ & 0.01 \\
\hline MEI, Mcal/day & $5.58^{\mathrm{d}}$ & $6.83^{\mathrm{c}}$ & $7.64^{\mathrm{b}}$ & $10.43^{\mathrm{a}}$ & 0.05 \\
\hline CPI, g/day & $429.59^{c}$ & $502.16^{\mathrm{b}}$ & $512.09^{\mathrm{b}}$ & $746.65^{\mathrm{a}}$ & 3.56 \\
\hline milk yield, kg/day & $2.37^{\mathrm{c}}$ & $2.66^{\mathrm{bc}}$ & $3.23^{\mathrm{bc}}$ & $3.78^{\mathrm{a}}$ & 0.14 \\
\hline lactose, $\%$ & 4.22 & 4.23 & 4.20 & 4.28 & 0.04 \\
\hline protein, $\%$ & 4.04 & 4.08 & 4.07 & 4.15 & 0.06 \\
\hline fat, $\%$ & 2.98 & 3.21 & 3.63 & 3.30 & 0.18 \\
\hline solid non fat, $\%$ & 9.24 & 9.34 & 9.26 & 9.51 & 0.06 \\
\hline total solid, $\%$ & 12.22 & 12.56 & 12.89 & 12.81 & 0.20 \\
\hline \multicolumn{6}{|l|}{ Overall } \\
\hline LW change, g/day & $-125.25^{\mathrm{a}}$ & $-106.57^{\mathrm{ab}}$ & $-62.69^{a b}$ & $-29.73^{b}$ & 9.75 \\
\hline lucerne hay intake, $\mathrm{kg}$ /day & $2.46^{\mathrm{a}}$ & $2.44^{\mathrm{a}}$ & $1.20^{\mathrm{c}}$ & $1.71^{\mathrm{b}}$ & 0.01 \\
\hline concentrate intake, $\mathrm{kg} /$ day & $0.45^{\mathrm{d}}$ & $0.89^{\mathrm{c}}$ & $1.75^{\mathrm{b}}$ & $2.48^{\mathrm{a}}$ & 0.01 \\
\hline DMI, kg/day & $2.90^{\mathrm{c}}$ & $3.33^{\mathrm{b}}$ & $2.95^{\mathrm{c}}$ & $4.18^{\mathrm{a}}$ & 0.01 \\
\hline MEI, Mcal/day & $6.23^{\mathrm{c}}$ & $7.52^{\mathrm{b}}$ & $7.64^{\mathrm{b}}$ & $10.66^{\mathrm{a}}$ & 0.03 \\
\hline CPI, g/day & $483.61^{\mathrm{d}}$ & $558.90^{\mathrm{b}}$ & $511.14^{c}$ & $804.87^{\mathrm{a}}$ & 2.16 \\
\hline milk yield, kg/day & $2.18^{\mathrm{c}}$ & $2.59^{\mathrm{bc}}$ & $3.11^{\mathrm{b}}$ & $3.92^{\mathrm{a}}$ & 0.13 \\
\hline lactose, $\%$ & $4.11^{\mathrm{b}}$ & $4.22^{\mathrm{b}}$ & $4.25^{\mathrm{ab}}$ & $4.40^{\mathrm{a}}$ & 0.03 \\
\hline protein, $\%$ & 3.90 & 3.91 & 3.95 & 3.97 & 0.05 \\
\hline fat, $\%$ & 2.92 & 2.82 & 3.36 & 2.77 & 0.15 \\
\hline solid non fat, $\%$ & $9.00^{\mathrm{b}}$ & $9.12^{\mathrm{ab}}$ & $9.21^{\mathrm{ab}}$ & $9.39^{\mathrm{a}}$ & 0.05 \\
\hline total solid, $\%$ & 11.92 & 11.94 & 12.57 & 12.15 & 0.16 \\
\hline
\end{tabular}

DMI - dry matter intake, MEI - metabolizable energy intake, CPI - crude protein intake 
Feeding methods had no significant $(\mathrm{P}>0.05)$ effects on fat, protein or dry matter contents of milk. However, lactose and non-fat-solids content were affected significantly $(\mathrm{P}<0.05)$ by feeding methods, as lactose and non-fat-solids content of the groups increased according to their concentrate intakes.

\section{DISCUSSION}

The results obtained in the present study showed that feed intake, milk yield, milk composition and liveweight changes were influenced by feeding methods.

Our results related to feed intake revealed that offering limited concentrate decreased total feed intake. The goats receiving limited concentrate $(0.5$ and $1.0 \mathrm{~kg}$ ) tried to compensate dry matter intake by consuming more hay as long as they had free access to hay, when compared to the TMR and choice-feeding groups. The results also showed that the groups receiving the limited amount of concentrate $(0.5$ and $1.0 \mathrm{~kg})$ consumed similar amounts of hay. This could be attributed to the physical properties of hay. Hay was used as stalk in $0.5,1 \mathrm{~kg}$ concentrate- supplemented- and choice-fed group. Masson et al. (1991) reported that goats receiving low and high amounts of concentrate $(900 \mathrm{~g}$ vs $700 \mathrm{~g} /$ day and $600 \mathrm{vs} 400 \mathrm{~g} /$ day) consumed similar amounts of green forage. On the other hand, Hadjipanayiotou and Morand-Fehr (1991) claimed that the level of roughage intake was higher when goats were allowed much time and abundant amounts of hay for selection. In our study, lucerne hay was given 3-4 times a day to prevent selection of leaves. This may have led the goats in both groups ( 0.5 and $1.0 \mathrm{~kg}$ concentrate) to consume similar amounts of hay.

In TMR and choice-feeding treatments, where the amount of concentrate was not solely limited, hay intake decreased significantly. These results suggest that increasing the amount of concentrate in the diet reduces roughage intake in goats. Similarly, Sauvant et al. (1991) reported that goats receiving $100 \mathrm{~g}$ supplemental concentrate consumed $111 \mathrm{~g}$ less forage dry matter. Although the goats fed on TMR and $0.5 \mathrm{~kg}$ concentrate consumed concentrate/roughage in different ratios, they consumed similar amounts of dry matter in our trial. Similarly, Goetsch et al. (2001) observed that goats fed diets with $20: 80,35: 65,50: 50$, or $65: 35$ concentrate/ roughage ratios consumed similar amounts of dry matter.

Our results also revealed that choice-feeding stimulated dry matter intake when compared with TMR; even consumed roughage and concentrate in which used in TMR (40:60; Table 3). These results suggested that free-choice feeding has a potential to increase dry matter intake in goats by giving the animals a chance to consume feed ingredients in a synchronized manner to improve the ruminal environment (stability of $\mathrm{pH}$, synchronization of nutrient supply to microorganisms in the rumen), as previously reported by Görgülü et al. (1996) for lambs, Abijaude et 
al. (2000) and Fedele et al. (2002) for goats. Additionally, Morand-Fehr et al. (1991) reported that feeding preference opportunities of goats on pasture and rangelands is higher than those in stalls because of the higher availability of feeds and feed types. Therefore, it may be speculated that choice-feeding in stalls or on pasture and rangeland may give goats a chance to select their diets and may improve their performance. Moreover, the goats in the choice-feeding group in our study changed the crude fibre content of the diets selected depending on the experimental period (17.25\% for weeks $1-4$ vs $15.06 \%$ for weeks $5-7$ ). The choice-fed goats consumed more feed and produced more milk in the first period of the study. Accordingly, they may have needed more fibre to maintain the rumen environment in desirable limits, to regulate digestion processes, stimulate rumination and salivation, and form a normal rumen mat to create a filter system that prevents rapid passage of particles and loss of nutrients (Van Soest et al., 1991). Fedele et al. (2002) also showed that choice-fed goats maintained the fibre content (NDF) almost constant, while the goats markedly changed the concentrate content (until 85\%) of the diet selected in different periods of their life cycle (dry period, lactation and late pregnancy).

Abijaude et al. (2000) also provide an explanation for increased concentrate intake in the choice-feeding group. They provided detailed information on the feeding behaviour of dairy goats; they observed that goats consumed marked amounts of feed by increasing the number of secondary meals when a high concentrate diet was offered. In other words, goats fed a high concentrate diet can consume marked amounts of feed by taking smaller meal size in shorter intervals. This type of feeding pattern could be expected to help the animal overloading the rumen with highly fermentable concentrate, which may cause significant decreases in microbial activity of the rumen.

Our results also showed that metabolizable energy and crude protein intakes were the highest for the choice-fed goats and the lowest for the goats receiving 0.5 $\mathrm{kg}$ concentrate. Metabolizable energy intake and crude protein intake were similar for the goats fed on TMR and $1.0 \mathrm{~kg}$ concentrate. These results were expected as feed intake mediates metabolizable energy and crude protein intakes. Goats receiving feed ingredients as free choices selected a diet that had higher crude protein (19.2 vs $17.3 \%$ ) and lower metabolizable energy (2.55 vs $2.59 \mathrm{Mcal} / \mathrm{kg}$ DM) values than the goats on TMR by selecting higher amounts of wheat bran, soyabean meal and lower amounts of barley than their individual levels used in TMR (Table 2). The high preferences of goats on choice-feeding for protein could be attributed to their high protein requirement for high milk yield, and the need for optimization of ruminal fermentation and also for buffering high acidity resulting from their high intake of concentrate. Moreover, high yielding goats may need more amino acids in the small intestine to maintain milk yield. It is reported that soyabean meal has high degradability in the rumen (Görgülü et al., 1999). When the protein source, soyabean, used in the present trial was considered, this could 
limit rumen escape protein (amino acids) to the small intestine, thus goats having high yielding capacity may need to consume more protein to maintain the amino acid supply to the small intestine.

The results with respect to diet selection showed that the nutrient intake of choicefed goats was higher than the recommendation made by NRC (1981). According to NRC (1981), goats, by size and milk yield similar to our choice-fed goats, require about 8.5 Mcal metabolizable energy and $378 \mathrm{~g}$ crude protein daily, however, our goats consumed about $20 \%$ more energy, and $50 \%$ more protein. This result suggests that the NRC (1981) recommendations for goats seem to be not totally valid for the suckling Damascus goats used under our experimental conditions.

In pasture or rangeland, goats may show preference for some plant species according to their availability and stage of maturity (Odo et al., 2001). Our choicefed goats in stalls had no limitation as to the availability of feed offered them. The main reason for preferences for some special feed ingredients given as free choices therefore probably depend on their nutrient contents, palatability and their effect on ruminal conditions, such as microbial growth, ruminal $\mathrm{pH}$, ammonia nitrogen, proportion of volatile fatty acids, passage rate, and rumen turnover rate. It has also been reported that one of the objectives of ruminants for selecting a diet is to maintain the rumen environment within a certain physiological range (Cooper et al., 1995; James et al., 2001). It has also been suggested that goats need to select a highly nutritious diet, as they have a relatively smaller body size and gastrointestinal tract capacity compared to other ruminants (Van Soest, 1982).

Fedele et al. (2002), who tested free-choice feeding by offering beet pulp, chick pea, broad beans, pasture hay and lucerne hay against traditional feeding, reported that lactating goats selected a diet with a higher protein/energy ratio at the beginning of lactation when compared with the later phase. Our findings support the results of Fedele et al. (2002); the goats in the choice-fed group changed feed ingredient preferences depending on the experimental period, decreasing the protein (19.7 vs $18.7 \%$ ) and increased metabolizable energy contents ( $2.49 \mathrm{vs} 2.61 \mathrm{Mcal} / \mathrm{kg} \mathrm{DM})$ of the selected diet as the trial progressed (in weeks 1-4 and 5-7 of the experiment).

Changes in preferences for feed ingredient and/or diets selected by goats and milk yield in different stages of lactation suggested that dairy goats may have the ability to associate the physical properties of feed ingredients with their physiological effects and select their diet according to their nutrient requirements. Additionally, choice-fed goats did not show any unusual feed preferences that lead to digestive problems, although they consumed relatively higher amounts of concentrate ( $2.48 \mathrm{vs}$ $1.75 \mathrm{~kg} /$ day) than the TMR group. This result may also suggest that when animals consume high amounts of concentrate, they simultaneously increase their roughage intake to optimize ruminal conditions.

Milk yields of the goats fed on free-choice feeding were higher than those of the other groups during all experimental periods. The goats receiving choice feeding 
yielded 80,51 and $26 \%$ more milk and experienced lower weight loss than the groups receiving $0.5,1.0 \mathrm{~kg}$ concentrate and TMR, respectively. These results once again suggest that high nutrient intake is the major factor for enhancing milk yield and maintaining body weight in early lactation. High nutrient intake increases the nutrient supply to mammary and adipose tissue for milk production and for body weight gain. Our results with respect to nutrient intake and milk yield in early lactation are in agreement with previous studies (Morand-Fehr and Sauvant, 1980; Gihad et al., 1987; Hadjipanayiotou, 1987; Mishra and Rai, 1996), in which dairy animals were reported to quickly respond to energy or protein balance during early lactation by increasing or decreasing milk yield.

Our results also showed that milk components were affected by feeding treatments; lactose and non-fat solid contents were increased by increasing concentrate and total dry matter intakes throughout treatments. Non-fat solid content of milk may change due to changes in protein content and occasionally lactose content. Although there were no differences in protein, fat and total protein contents of milk among the feeding methods, there was a tendency for the fat content to decrease and the protein content to increase, while significant increases in the lactose content occurred depending on the concentrate intake. It has been reported that the SNF content in cow milk (Harris and Bachman, 2002) and lactose content in late lactation in goats (Goetsch et al., 2001) increased as the concentrate intake increased. It is well known that lactose plays a major role in milk synthesis, and it draws water into milk in mammary epithelial cells (Thomas and Martin, 1988). Therefore, the increase in milk yield in the present study could also be explained by the increase in concentrate intake, which stimulates lactose synthesis in mammary tissue.

\section{CONCLUSIONS}

The results obtained in this study suggest that TMR may give satisfactory results in feeding lactating suckling goats when compared with conventional feeding with 0.5 or $1 \mathrm{~kg}$ concentrate with ad libitum lucerne hay. The results also suggest that dairy goats may have the ability to associate physical properties of feed ingredients (ground barley, soyabean meal, wheat bran and lucerne hay) with their physiological effects and select their diet according to their nutrient requirements, attaining better lactation performance. Under these circumstances, choice feeding offers some potential advantages by providing a simple methodology to ascertain nutrient requirement of dairy goats and/or to evaluate feed ingredients and diet formulation and preparation. 


\section{REFERENCES}

Abijaude J.A., Moran-Fehr P., Tessier J., Schmidely Ph., Sauvant D., 2000. Diet effect on the daily feeding behaviour, frequency and characteristics of meals in dairy goats. Livest. Prod. Sci. 64, 29-37

AFRC, 1998. The Nutrition of Goats. CAB International, Wallingford (UK)

AOAC, 1998. Association of Official Analytical Chemists, Official Methods of Analysis. $16^{\text {th }}$ Edition. Washington, DC

Archimede H., Sauvant D., Herview J., Poncet C., Dorleans, M., 1995. Digestive interactions in the ruminant: Relationships between whole tract and stomach evaluation. Anim. Feed Sci. Tech. 54, 327-340

Cerillo M.A., Russell J.R., Crump M.H., 1999. The effects of hay maturity and forage to concentrate ratio on digestion kinetics in goats. Small Ruminant Res. 32, 51-60

Cooper S.D.B., Kyriazakis I, Nolan J.V., 1995. Diet selection in sheep - the role of rumen environment in the selection of a diet from 2 feeds that differ in their energy density. Brit. J. Nutr. 74, 35-54

Fedele V., Claps S., Rubino R., Calandrelli M., Pilla A.M., 2002. Effect of free-choice and traditional feeding systems on goat feeding behaviour and intake. Livest. Prod. Sci. 74,19-31

Fox D.G., Sniffen C.J., O’Conor J.D., Russell J.B., Van Soest P.J., 1990. The Cornell Net Carbohydrate Protein System for evaluating cattle diets. Search Agriculture. Cornell University, Agriculture Experimental Station, No. 34. Ithaca, NY

Gihad E.A., El-Gallad T.I., Allam S.M., El-Bedawy T.M., 1987. Effect of pre-and post-partum nutrition of birth weight and early milk yield in goats. In: Proceeding of $4^{\text {th }}$ International Conference on Goats. Brasilia (Brasil), Vol 2, pp.1401-1402

Goetch A.L., Detweiler G., Sahlu T., Puchala R., Dawson L.J., 2001. Dairy goat performance with different dietary concentrate levels in late lactation. Small Ruminant Res. 41, 117-125

Görgülü M., Baykal L., Kutlu H.R. Ataşoğlu C., 1999. Determination of nitrogen degradability of some different protein sources by in situ technique. Proceeding of the British Society of Animal Science, p. 92

Görgülü M., Kutlu H.R., Demir E., Öztürkcan O., Forbes J.M., 1996. Nutritional consequences of free choice among feed ingredients by Awassi lambs. Small Ruminant Res. 20, 23-29

Hadjipanayiotou M., 1987. Studies on reponse of lactating Damascus Goats to dietary protein. J. Anim. Physiol. Anim. Nutr. 57, 41-52

Hadjipanayiotou M., Morand-Fehr P., 1991. Intensive feeding of dairy goats. In: P. Morand-Fehr (Editor). Goat Nutrition. EAAP, Wageningen, pp.197-208

Harris B., Bachman K.C., 2002. Nutritional and Management Factors Affecting Solid-Not-Fat, Acidity and Freezing Point of Milk. University of Florida, Cooperative Extension Service. Institute of Food and Agricultural Science. URL:http://edis.ifas.ufl.edu/BODY DS156

James S.M., Kyriazakis I., Emmans G.C., 2001. Diet selection of sheep: effects of adding urea to foods with different protein contents. Anim. Sci. 73, 183-195

Kutlu H.R., Forbes J.M., 1993. Self selection of ascorbic acid in coloured foods by heat-stressed broiler chicks. Physiol. Behav. 53, 103-110

Kyriazakis I., Oldham J.D., 1993. Diet selection in sheep: the ability of growing lambs to select a diet that meets their crude protein (nitrogen x 6.25) requirements. Brit. J. Nutr. 58, 765-772

Linn J.G., Hutjens M.F., Shaver R., Otterby D.E., Howard W.T., Kilmer L.H., 1994. Feeding the Dairy Herd. North Central Regional Extension Publ. No. 346. Minnesota Extension Service. University of Minnesota, College of Agriculture

Masson C., Rubino R., Fedele V., 1991. Forage utilization in goats. In: P. Morand-Fehr (Editor). Goat Nutrition. EAAP, Wageningen, pp.145-159 
Mishra S., Rai S.N., 1996. Effects of different RDP and UDP ratios on voluntary intake, milk production and feed conversion efficiency in lactating goats. Small Ruminant Res. 20, 31-38

Morand-Fehr P., Owen E., Giger-Reverdin S., 1991. Feeding behaviour of goats at the trough. In: P. Morand-Fehr (Editor). Goat Nutrition. EAAP, Wageningen, pp. 3-12

Morand-Fehr P., Sauvant D., 1980. Composition and yield of goat milk as affected by nutritional manipulation. J. Dairy Sci. 63, 1671-1680

NRC., 1981. Nutrient Requirements of Goat. National Academy Press, Washington, DC

Odo B.I., Omeje F.U., Okwor J.N., 2001. Forage species availability, food preference and grazing behaviour of goats in south eastern Nigeria. Small Ruminant Res. 42, 163-168

SAS, 1985. Statistical Analyses System, SAS User's Guide: Statistics. SAS Institute, Inc., Carry, $\mathrm{NC}$

Sauvant D., Morand-Fehr P., Giger-Reverdin S., 1991. Dry matter intake of adult goats. In: P. MorandFehr (Editor). Goat Nutrition. EAAP, Wageningen, pp. 25-36.

Sutton J.D., Alderman G., 2000. The energy and protein requirements of pregnant and lactating dairy goats. The Agriculture and Food Research Council Report. Livest. Prod. Sci. 64, 3-8

Thomas P.C., Martin P.A., 1988. The influence of nutrient balance on milk yield and composition. In: P.C. Garnsworthy (Editor). Nutrition and Lactation in the Dairy Cow. Butterworths, pp. 97-118

Van Soest P.J., 1982. Nutritional Ecology of the Ruminant. O. and B. Books, Corvallis, OR

Van Soest P.J., Robertson J.B., Lewis B.A., 1991. Methods for dietary fiber, neutral detergent fiber, and nonstarch polysaccarides in relation to animal nutrition. J. Dairy Sci. 74, 3583-3597

\section{STRESZCZENIE}

\section{Alternatywny system żywienia kóz mlecznych i wpływ dowolnego wyboru paszy na wydajność i skład mleka karmiących kóz damasceńskich}

Celem badań było porównanie metod żywienia karmiących kóz damasceńskich i ich wpływ na produkcję i skład mleka oraz oznaczenie preferencji diet przy dowolnym wyborze pasz w warunkach północnego Cypru. Trzydzieści sześć kóz podzielono na 4 grupy, po 3 powtórzenia w każdej: grupa 1 otrzymywała do woli siano z lucerny i $0,5 \mathrm{~kg}$ paszy treściwej dziennie, grupa 2 - siano do woli i 1,0 kg paszy treściwej, grupa 3 - do woli dawkę TMR, zawierającą $40 \%$ siana z lucerny i $60 \%$ paszy treściwej, grupa 4 - żywienie oparte na dowolnym wyborze pasz; w skład dawki wchodziło siano z lucerny oraz pasze treściwe (jęczmień, śruta poekstrakcyjna sojowa, otręby pszenne). Doświadczenie trwało 7 tygodni.

Produkcja mleka, pobranie paszy treściwej i siana, całkowite pobranie paszy, a także ilość pobranego białka ogólnego i energii metabolicznej oraz zmiany masy ciała zależały $(\mathrm{P}<0,05)$ od zastosowanego systemu żywienia. Przy dowolnym wyborze pasz (grupa 4) pobranie s.m., energii i białka oraz produkcja mleka były większe, przy zmiejszonych stratach m.c. System żywienia nie miał wpływu na zawartość tłuszczu, białka i s.m. w mleku. Zawartość laktozy i s.m. beztłuszczowej zwiększała się natomiast istotnie $(\mathrm{P}<0,05) \mathrm{w}$ miarę zwiększania pobrania paszy treściwej.

W podsumowaniu można stwierdzić, że przy zastosowaniu systemu żywienia TMR otrzymuje się dobre wyniki dotyczące użytkowości mlecznej karmiących kóz gdy mogą one wybierać dowolnie pasze z diety zgodnie z zapotrzebowaniem. Wykazano także, że żywienie oparte na dowolnym wyborze pasz może przyczynić się do poprawy wyników produkcyjnych kóz damasceńskich we wczesnym okresie laktacji. 